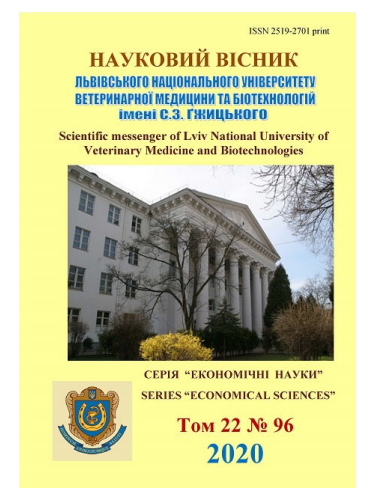

Науковий вісник Дьвівського національного університету ветеринарної медицини та біотехнологій імені С.3. Гжицького.

\author{
Серія: Економічні науки
}

\author{
Scientific Messenger of Lviv National University \\ of Veterinary Medicine and Biotechnologies. \\ Series: Economical Sciences
}

ISSN 2519-2701 print

https://nvlvet.com.ua/index.php/economy

doi: 10.32718/nvlvet-e9603

UDC 631.95:341.221.27(477+438)

\title{
Environmental security in rural areas near the Ukrainian-Polish border: comparative analysis
}

\author{
I. Kulish ${ }^{1}$, M. Yankiv², S. Fetko ${ }^{3}$, V. Liublin ${ }^{4}$ \\ ${ }^{1}$ State institution "Institute of Regional Research named after M. I. Dolishniy of the NAS of Ukraine" Lviv, Ukraine \\ ${ }^{2}$ Lviv Institute of Management, Lviv, Ukraine \\ ${ }^{3}$ Institution Open International University of Human Development "Ukraine”, Kyiv, Ukraine \\ ${ }^{4}$ Lviv State University of Life Safety, Lviv, Ukraine
}

\section{Article info}

Received 13.11.2020

Received in revised form 14.12.2020

Accepted 15.12.2020

State institution "Institute of Regional Research named after M. I. Dolishniy of the NAS of Ukraine”, Kozelnytska Str., 4, Lviv 79026, Ukraine.

Tel.: +38-032-270-71-68

E-mail:reksi@email.ua

Lviv Institute of Management,

Liska Str., 16, Lviv, 79000,

Ukraine.

Institution Open International University of Human Development "Ukraine", Lvivska Str., 23, Kyiv, 03115, Ukraine.

Lviv State University of Life Safety, Kleparivska Str., 35, Lviv,

79007, Ukraine.
Kulish, I., Yankiv, M., Fetko, S., \& Liublin, V. (2020). Environmental security in rural areas near the Ukrainian-Polish border: comparative analysis. Scientific Messenger of Lviv National University of Veterinary Medicine and Biotechnologies. Series: Economical Sciences, 22(96), 15-20. doi: $10.32718 /$ nvlvet-e9603

A comparative analysis of the ecological safety of rural areas of the Ukrainian-Polish border was conducted. The main statistical indicators characterizing the natural environment on both sides of the Ukrainian-Polish border have been studied. The possibility of using indicators of the state of ecology of rural areas used for statistical purposes in Ukraine and Poland has been studied. The degree of implementation of the provisions of the "Association Agreement between Ukraine, on the one hand, and the European Union, the European Atomic Energy Community and their Member States, on the other hand" on the unification of statistics was analyzed and found to be incomplete. Indicators used for statistics in Poland (EU) and Ukraine differ significantly, which greatly prevents a full comparison of the environment and living conditions, which a priori determine the quality of life, its duration, the health of residents on both sides of the border. This situation complicates the planning of joint Ukrainian-Polish activities in all areas covered by the concept of "environmental security in the cross-border area". It was emphasized that Ukraine has undertaken to harmonize the Ukrainian statistical system with the European Statistical System, as well as to support the introduction of a common quality management system in all processes of production and distribution of statistical products, but this activity is very slow. It is revealed that due to this situation the cooperation between the parties within the European Statistical System, namely Eurostat as the EU statistical body, in the field of environmental statistics remains low. It is proved that the presence of a large number of border crossings in border areas are additional (compared to other local areas) centers of agricultural soil pollution: increasing air emissions and solid waste, consuming more water, respectively, increases the amount of wastewater and the load on treatment plants. At the same time, there is a constant threat of transboundary pollution and accidents of water supply systems, and consequently, the release of emissions of varying degrees of danger into water and soil. The need to conduct further research to study the structure of agricultural production of the Ukrainian-Polish borderland with an emphasis on organic production and consumption was noted.

Key words: rural areas, environmental safety, borderland, Ukraine, Poland.

\section{Екологічна безпека сільських територій поблизу українсько-польського кордону: компаративний аналіз}

\author{
I. Куліш ${ }^{1}$, М. Янків ${ }^{2}$, С. Фетько ${ }^{3}$ В. Люблін ${ }^{4}$ \\ 'Державна установа “Інститут регіональних досліджень ім. М. І. Долішнього НАН Украӥни”, м. Львів, Украӥна \\ ${ }^{2}$ Львівський інститут менеджменту, м. Львів, Украӥна
}


${ }^{3}$ Відкритий міжнародний університет розвитку людини “Украӥна”, м. Київ, Украӥна

${ }^{4}$ Львівський державний університет безпеки життєдіяльності, м. Львів, Украӥна

Проведено компаративний аналіз екологічної безпеки сільських територій украӥнсько-польського прикордоння. Вивчено основні статистичні показники, що характеризують природне навколищнє середовище по обидва боки українсько-польського кордону. Досліджено можливість використання однакових індикаторів стану екології сільських територій, що використовуються для потреб статистики в Украӥні та Польщі. Проаналізовано ступінь виконання положень "Угоди про асоціацію між Україною, 3 однієї сторони, та Свропейським Союзом, Свропейським співтовариством з атомної енергії $і$ їхніми державами-членами, з іншоі сторони" щодо уніфікаиї статистичних показників і встановлено, що вона не завершена. Показники використовувані для потреб статистики у Польщі (СС) і Україні суттєво відрізняються, що великою мірою перешкоджає проведенню повного порівняння стану навколишнього середовища і умов життя населення, які апріорі визначають якість життя, його тривалість, стан здоров'я жителів територій з обох боків кордону. Така ситуація ускладнює планування спільних украӥнсько-польських заходів в усіх сферах, що охоплюються поняттям “екологічна безпека у транскордонному просторі". Наголошено, ще Украӥна брала на себе обов'язок гармонізувати українську статистичну систему з Свропейською статистичною системою, а також підтримувати впровадження загальної системи управління якістю в усі прочеси виробництва та поширення статистичної продукиії, однак ия діяльність ведеться дуже повільними темпами. Розкрито, що у зв'язку з ситуацією, що склалась на співробітництві сторін в рамках Європейської статистичної системи, а саме Свростату як статистичного органу ЄС, у сфері статистики навколишнього середовища залишається на низькому рівні. Доведено, щь наявність великої кількості пунктів пропуску через кордон є додатковими (порівняно з іншими територіями крайн) осередками забруднення трунтів сільськогосподарського призначення: зростають викиди у атмосферне повітря та кількість твердих відходів, споживається більше води, відповідно збільшується кількість стічних вод і навантаження на очисні споруди. При цьому існує постійна загроза транскордонного забруднення і аварій систем водопостачання, а отже, потрапляння викидів різного ступеню небезпеки у водні та трунтові об 'єкти. Відзначена необхідність проведення подальшого дослідження з вивчення структури сільськогосподарського виробництва українсько-польського прикордоння $з$ акцентуванням уваги на органічному виробнищтві і споживанні.

Ключові слова: сільські території, екологічна безпека, прикордоння, Україна, Республіка Польща.

\section{Ветуп}

Важливість екологічної безпеки у сьогоднішньому високорозвиненому технічному світі складно переоцінити. Негативний вплив людства на головні природні ресурси: повітря, воду, землю, постійно збільшується. Зростає споживання, а отже і збільшується кількість відходів, тому виникає необхідність їх обліку та утилізації. 3 цієї точки зору великого значення набувають прикордонні території, особливо якщо наявні спільні як поверхневі, так і підземні водойми. 3 урахуванням постійного розвитку транспортних мереж зростає загроза інвазії нетипових для певних територій представників флори та фауни.

Мета $і$ завдання дослідження: метою цього дослідження стало проведення порівняльного аналізу екологічного стану прикордонних сільських територій України та Польщі. Завдання дослідження: вивчити основні статистичні показники, що використовуються у обох країнах; дослідити можливість проведення їх уніфікації основних індикаторів екологічного стану сільських територій прикордоння; встановити ступінь виконання відповідних положень "Угоди про асоціацію між Україною, з однієї сторони, та Європейським Союзом, Європейським співтовариством 3 атомної енергії і їхніми державами-членами, з іншої сторони" (Ugoda..., 2014) (далі - Угода).

\section{Матеріал і методи досліджень}

У всіх країнах світу проблема збереження природних ресурсів стоїть дуже гостро. Немає жодної національної політики, у якій би не приділялась увага питанням екологічної безпеки. Дану проблему не оминають увагою і науковці. Доволі інформативними $є$ офіційні статистичні джерела та публікації. Над досліджуваною у статті тематикою працювали такі вчені:
- Новотни Я. і Везіроглу Т. Н. (Nowotny \& Veziroglu, 2019) досліджували можливості переходу на альтернативні екологічно чисті джерела енергії;

Белей C. i Лужинський В. (Belej \& Luzhyns'kyj, 2020) запропонували розглядати сільські території прикордоння як центри євро регіонального співробітництва;

- Кузубов А. (Kuzubov, 2017) розглянув основні механізми виробництва екологічно безпечної сільськогосподарської продукції;

Зеліч В. (Zelich, 2018) згрупував теоретичні засади співробітництва у транскордонному просторі 3 врахуванням екологічної складової;

Сур'яна Н. К. і Пуджіваті Е. Х. виділили основні проблеми забезпечення продовольчої безпеки прикордонних територій (Suryana \& Pudjiwati, 2017);

- Девід С. Солсбері, Хосе Борго Лопес, Хорхе В. Вела Альварадо дослідили особливості транскордонної політичної екології (Salisbury et al., 2011);

для проведення грунтовного дослідження необхідно також аналізувати нормативно-правові документи у цій сфері, програми, плани та офіційні статистичні дані.

\section{Результати і їх обговорення}

До безпосередньо прикордонних з Польщею з боку України субрегіонів належать райони:

- у Волинській області - Шацький, Любомльський, Володимир-Волинський, Іваничівський;

- у Закарпатській області - Великоберезнянський;

- у Львівській області - Сокальський), Жовківський, Яворівський, Мостиський, Старосамбірський, Турківський.

Прикордонними з Україною є повіти Польщі:

- у Люблінському воєводстві - Більський, Володавський, Холмський, Грубешівський, Томашівський;

- у Підкарпатському воєводстві - Любачівський, 
Ярославський, Перемишльський, Бещадський.

Довжина польсько-українського кордону у Підкарпатському воєводстві становить 236 км, у Любельському - 299 км. Усього на українсько-польському кордоні функціонує 17 пунктів пропуску та пунктів контролю:

- 8 автомобільних пунктів пропуску: "Рава-Руська" (“Хребенне”), “Шегині” (“Медика”), “Ягодин” (“Дорогуськ”), “Устилуг” (“Зосін”), “Краківець” (“Корчова”), “Смільниця” (“Кросьценко”), “Грушів” (“Будомєж”), “Угринів” (“Долгобичув”);

- 6 залізничних пунктів пропуску: "Рава-Руська" (“Верхрата"), “Рава-Руська" ("Хребенне”), “Хирів” (“Кросьценко”), “Ягодин” (“Дорогуськ”), “Володимир-Волинський” (“Хрубешув”), “Мостиська” ("Пшемисль");

- 3 пункти контролю: “Лудин”, “Ізов”, “Львів”.

Територіальним об'єктом проведеного дослідження було обрано суміжні субрегіони Львівської області (Сокальський, Жовківський, Яворівський райони) та Підкарпатського воєводства (Любачівський, Ярослав- ський, Перемишльський повіти).

Стан забруднення повітряного басейну Львівської області протягом останнього десятиріччя залишається майже незмінним. Це однак не свідчить про відсутність заходів щодо зменшення викидів у атмосферне повітря, в рамках “Програми скорочення викидів забруднюючих речовин в атмосферне повітря стаціонарними джерелами найбільших підприємствзабруднювачів Львівської області на 2009-2017 рр.”, затвердженої розпорядженням голови Львівської обласної державної адміністрації від 26.11.2009 р. № 1269/0/5-09, було виконано 85 заходів, що дало змогу зменшити викиди оксиду азоту, сірчистого ангідриду, речовин у вигляді суспендованих твердих частинок тощо (Departament ekologii').

3 трьох районів Львівщини найбільше забруднене атмосферне повітря у Сокальському - 23159 т викидів на рік, що пояснюється наявністю діючих вугільних шахт у м. Червонограді (13629 т/рік), у Яворівському районі - 727 т/рік, Жовківському - 407 т/рік (рис. 1).

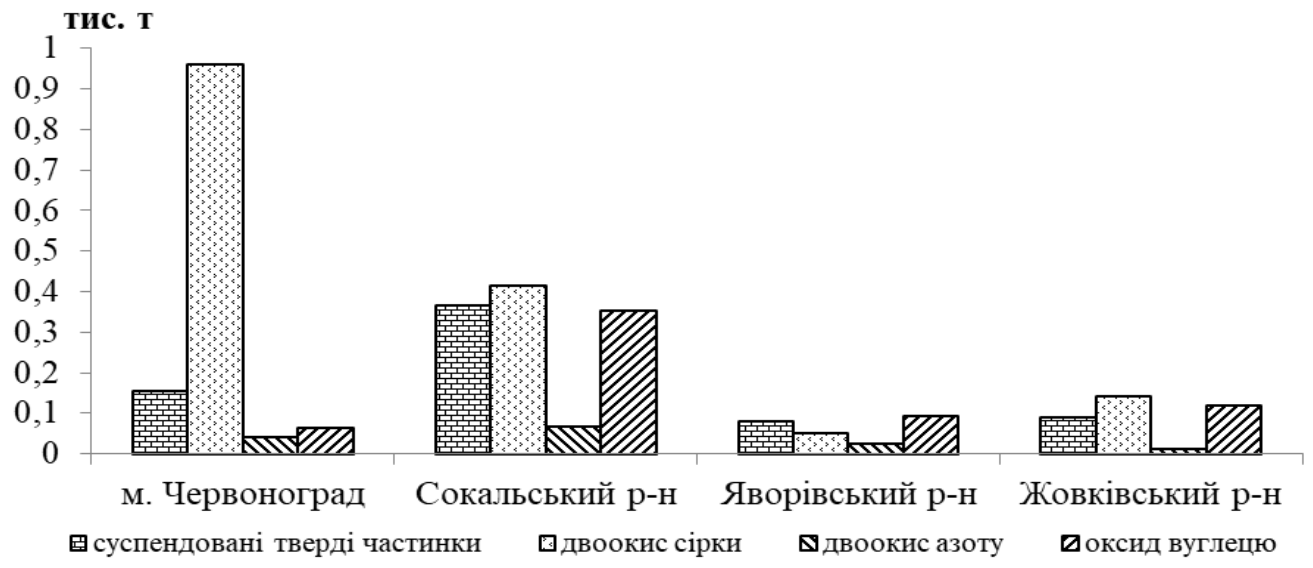

Рис. 1. Динаміка викидів стаціонарними джерелами в атмосферне повітря

Джерело: розроблено за даними (Regional'na dopovid'..., 2020)

Більша частина забруднення повітря у прикордонних районах Львівщини надходить від промислових та переробних підприємств - 44 \%, від мереж газо-, електро-, паропостачання та кондиціонування повітря - 38 \% забруднення від інших видів економічної дія- льності є значно меншим.

Поверхневі води Жовківського, Сокальського та Яворівського районів, не зважаючи на низку заходів, продовжують належати до числа забруднених.

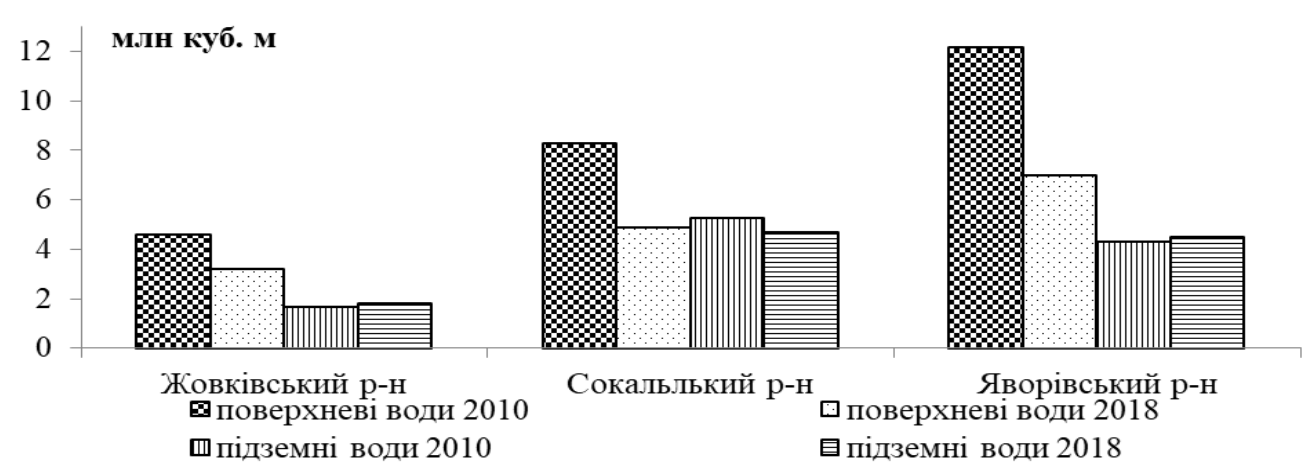

Рис. 2. Динаміка забору води з природних водних об'єктів у 2010-2018 рр., млн куб. м. Джерело: розроблено за даними (Dovkillja L'vivs'koi' oblasti, 2018) 
Серед основних негативних чинників впливу (Regional'na dopovid'..., 2020):

- занечищення грунтів і атмосфери;

- зміна ландшафтної структури;

- техногенне перевантаження території;

- неефективна робота каналізаційно-очисних споруд;

- неправильне визначення та облаштування прибережних захисних смуг і водоохоронних зон, недотримання правил поводження з ними, насамперед у населених пунктах;

- забруднення та засмічення річок побутовими та іншими відходами;

- трелювання лісу по потоках.
Забір води з природних водних об'єктів суттєво скоротився (див. рис. 2). При цьому співвідношення використання води для різних потреб залежить від структури виробництва на кожній окремо взятій території (див. табл. 1).

У рамках програм збереження води і внаслідок зміни у структурі виробництва змінились обсяги оборотного та повторно-послідовного водопостачання, що за період 2010-2018 рр. становило:

- зросло на 0,1 млн куб. м у Жовківському р-ні;

- зменшилось 3 10,9 до 3,0 млн куб. м у Сокальському р-ні;

- зросло на 9,7 млн куб м у Яворівському р-ні.

Таблиця 1

Використання свіжої води за видами потреб у 2018 р., млн куб. м

\begin{tabular}{lcccc}
\cline { 2 - 5 } & Виробництво & Побутово-питні потреби & Сільське господарство & Усього \\
\hline Жовківський р-н & 2,1 & 0,7 & 0,6 & 3,3 \\
Сокальський р-н & 1,7 & 1,2 & 1,1 & 4,1 \\
Яворівський р-н & 4,9 & 2,4 & 1,4 & 6,8 \\
\hline
\end{tabular}

Джерело: розроблено за даними (Dovkillja L'vivs'koi' oblasti, 2018)

Водовідведення у поверхневі водні об'єкти у 2010-2018 рр. змінилось неістотно і виглядає наступним чином:

- у Жовківському р-ні - 1,5-2,0 млн куб. м, 3 них забруднені - 0,5-0,5 млн куб. м;

- у Сокальському р-ні - 1,4-1,0 млн куб. м, 3 них забруднені - 1,0-1,0 млн куб. м;

- у Яворівському р-ні - 4,1-4,2 млн куб. м, 3 них забруднені - 0,2-0,5 млн куб м.

Скорочення кількості забруднених вод, що поступають у поверхневі водойми зросло у Яворівському рні, залишилось без змін у Сокальському та Жидачівському.

Потужність очисних споруд за досліджуваний період зросла на 0,2 млн куб. м у Жовківському р-ні; зменшилась на 1,2 млн куб. м у Сокальськомур-ні і на 5,4 млн куб. м у Яворівському районі.

Контроль якості поверхневих вод у транскордонних ріках здійснюється Басейновим управлінням водних ресурсів річок Західного Бугу та Сяну (результати контролю див. табл. 2). Якість води у ріках з української та польської сторін $є$ ідентичною.

Згідно з інформацією Головного управління Держгеокадастру у Львівській області державна статистична звітність $з$ кількісного обліку земель заповнялася лише до 01.01.2016 р. Контроль стану грунтів на сьогодні здійснює ДУ “Держгрунтохорона”. У зв’язку із малою потужністю установи, за 2018 р. 3 1261,5 тис. га сільгоспугідь було обстежено 36,59 тис. га, що становить 2,9 \% від загальної площі.

Таблиця 2

Результати моніторингових досліджень стану поверхневих вод у транскордонних ріках

\begin{tabular}{|c|c|c|c|c|c|c|c|c|c|}
\hline \multirow{2}{*}{$\begin{array}{l}\text { № } \\
\Pi / \Pi\end{array}$} & \multirow{2}{*}{$\begin{array}{l}\text { Назва } \\
\text { водотоку }\end{array}$} & \multirow[b]{2}{*}{ Назва створу } & \multirow{2}{*}{$\begin{array}{l}\text { Кількість } \\
\text { відборів }\end{array}$} & \multirow{2}{*}{$\begin{array}{c}\text { Кількість } \\
\text { компоненто- } \\
\text { визначень }\end{array}$} & \multirow{2}{*}{$\begin{array}{c}\text { Кількість } \\
\text { перевищень }\end{array}$} & \multicolumn{4}{|c|}{ \% перевищень } \\
\hline & & & & & & 2019 & 2018 & 2017 & 2016 \\
\hline 1. & р. Шкло & с. Краковець & 4 & 96 & 17 & 17,7 & 22,11 & 18,69 & 19,23 \\
\hline 2. & p. Вишня & с. Чсрневе & 6 & 144 & 13 & 9,0 & 8,6 & 8,7 & 6,73 \\
\hline 3. & p. Вишня & $\begin{array}{l}\text { м. Мостиська, відстань від гирла } \\
19 \text { км }\end{array}$ & 10 & 240 & 19 & 7,9 & - & - & - \\
\hline 4. & р. Завалівка & с. Грушів, відстань від гирла 12 км & 4 & 96 & 5 & 5,2 & 7 & 6 & 4 \\
\hline
\end{tabular}

Джерело: (Regional'na dopovid'..., 2020)

Рекультивація та відновлення грунтів області перебуває на дуже низькому рівні: 3 12,06 тис. га порушених земель було рекультивовано 0,02 тис. га. Наявність порушених і відпрацьованих земель за районами становить:

- Жовківський р-н: відповідно 360 та 224 га;

- Сокальський р-н: 669 та 300 га;

- Яворівський р-н: 3154 та 3009 га.

На територіях районів розташовані кілька підприємств, що є значними забруднювачами грунтів. Існує також багато невеликих за площею сміттєзвалищ.
Екологічна ситуація у досліджуваних субрегіонах Польщі дещо відрізняється. Любельське воєводство є одним 3 найбільш екологічно чистих регіонів Польщі. Тим не менше, існують загрози довкіллю природного та антропогенного характеру, визначення яких 3 наступною протидією є однією з основних цілей екологічної політики воєводства.

Основними джерелами забруднення атмосферного повітря (див. табл. 4) є антропогенні викиди внаслідок промислового виробництва, транспортних мереж і 3 житлового сектора. 


\section{Таблищя 4}

Емісія і скорочення забруднюючих речовин у атмосферне повітря

\begin{tabular}{|c|c|c|c|c|c|c|}
\hline \multirow{3}{*}{ Повіт } & \multicolumn{4}{|c|}{ Емісія забруднюючих речовин, т } & \multirow{2}{*}{\multicolumn{2}{|c|}{$\begin{array}{c}\text { Забруднюючі речовини, вловлені очисними } \\
\text { спорудами у \% до загальної кількості забруднюючих } \\
\text { речовин }\end{array}$}} \\
\hline & \multicolumn{2}{|c|}{ тверді } & \multicolumn{2}{|c|}{$\begin{array}{c}\text { газоподібні (без двоокису } \\
\text { вуглецю) }\end{array}$} & & \\
\hline & усього & $\begin{array}{c}\text { У т.ч. від } \\
\text { спалювання }\end{array}$ & усього & $\begin{array}{l}\text { У т.ч. двоокис } \\
\text { сірки }\end{array}$ & тверді & газоподібні (без двоокису вуглецю) \\
\hline Ярославський & 19 & - & 1085 & 203 & 78,7 & - \\
\hline Любачівський & 4 & 2 & 4 & 1 & 20,0 & - \\
\hline Перемишльський & 2 & 2 & 15 & 2 & 84,6 & 11,8 \\
\hline
\end{tabular}

Джерело: за матеріалами (Urząd Statystyczny w Lublinie)

Екологічний менеджмент чинить значний вплив на якість окремих елементів навколишнього природного середовища. Раціональне управління водопостачанням та каналізацією, зокрема будівництво та модернізація очисних споруд і розширення мереж каналізації, істотно поліпшило і продовжує поліпшувати стан поверхневих грунтових вод, у тому числі й у спільних 3 Україною водоймах.

Практично усі промислові й комунальні стоки проходять очищення. Без очищення скидається лише $0,6 \%$ стічних вод (табл. 5 ).

\section{Таблиця 5}

Промислові та комунальні стоки, населення, що користується очисними спорудами

\begin{tabular}{|c|c|c|c|c|c|c|c|}
\hline \multirow{3}{*}{ Регіон } & \multirow[b]{2}{*}{ Усього } & \multicolumn{4}{|c|}{ Очищення } & \multirow{3}{*}{$\begin{array}{c}\text { Не очи- } \\
\text { щуються, } \\
\text { dam }^{3}\end{array}$} & \multirow{3}{*}{$\begin{array}{c}\text { Населення, що } \\
\text { користується очисними } \\
\text { спорудами у \% до } \\
\text { загальної кількості } \\
\text { населення } \\
\end{array}$} \\
\hline & & усього & механічна & $\begin{array}{c}\text { хімічна і } \\
\text { біологічна }\end{array}$ & $\begin{array}{c}3 \text { посиленим } \\
\text { усуненням біогенів }\end{array}$ & & \\
\hline & $\mathrm{da}$ & & & $\%$ & & & \\
\hline Ярославський & 3614,0 & 3614,0 & - & 44,3 & 55,7 & - & 80,7 \\
\hline Любачівський & 1625,0 & 1588,0 & - & 63,0 & 37,0 & 37,0 & 81,4 \\
\hline Перемишльський & 1480,0 & 1480,0 & - & 80,7 & 19,3 & - & 61,0 \\
\hline
\end{tabular}

Джерело: за матеріалами (Urząd Statystyczny w Lublinie)

Поводження з відходами у досліджуваних субрегіонах організоване на достатньо високому рівні. Спостерігається зменшення обсягів відходів. Усі вони передаються на перероблення й складування відходів відсутне (табл. 6).

Загалом екологічна ситуація у прикордонних суб- регіонах Польщі значно краща ніж з боку України. Разом з тим є істотні труднощі у порівнянні статистичних показників наших країн, що перешкоджає проведенню детального порівняння стану навколишнього середовища і умов життя населення, які апріорі визначають його якість.

\section{Таблиця 6}

Відходи, що складуються (нагромаджуються) та площі їх складування

\begin{tabular}{|c|c|c|c|c|c|c|c|}
\hline \multirow{3}{*}{ Повіт } & \multicolumn{6}{|c|}{ Відходи у тис. т } & \multirow{3}{*}{$\begin{array}{c}\text { площі під складу- } \\
\text { ванням відходів, не } \\
\text { рекультивовані } \\
\text { станом на кінець } \\
\text { року, га }\end{array}$} \\
\hline & \multicolumn{5}{|c|}{ вироблені протягом року } & \multirow{2}{*}{$\begin{array}{c}\text { тимчасово } \\
\text { складовані } \\
\text { (нагромаджені } \\
\text { станом на кінець } \\
\text { року) }\end{array}$} & \\
\hline & усього & $\begin{array}{c}\text { піддані } \\
\text { відновленню }\end{array}$ & $\begin{array}{l}\text { знешко- } \\
\text { джені }\end{array}$ & $\begin{array}{c}\text { передан1 } \\
\text { іншим } \\
\text { особам }\end{array}$ & $\begin{array}{c}\text { у тимчасовому } \\
\text { запасі }\end{array}$ & & \\
\hline Ярославський & 14,4 & - & - & 14,4 & - & - & - \\
\hline Любачівський & 2,2 & - & - & 2,2 & - & - & - \\
\hline Перемишльський & 6,8 & - & - & 6,8 & - & - & - \\
\hline
\end{tabular}

Джерело: за матеріалами (Urząd Statystyczny w Lublinie)

Згідно Угоди передбачалось тісне співробітництво у сфері охорони навколишнього середовища (глава 7). Однак, відсутність уніфікації статистичних показників робить складним планування спільних заходів в усіх сферах, що охоплюються такою співпрацею, особливо в транскордонному просторі:

а) зміна клімату; b) екологічне управління та аналогічні питання, зокрема освіта й навчальна підготовка, доступ до інформації з питань навколишнього середовища та процесу прийняття рішень;

c) якість атмосферного повітря;

d) якість води та управління водними ресурсами, включаючи морське середовище; 
е) управління відходами та ресурсами;

f) охорона природи, зокрема збереження і захист біологічного та ландшафтного різноманіття (екомережі);

g) промислове забруднення і промислові загрози;

h) хімічні речовини;

i) генетично-модифіковані організми, в тому числі у сільському господарстві;

ј) шумове забруднення;

k) цивільний захист, зокрема стихійні лиха і антропогенні загрози;

1) міське середовище;

m) екологічні збори.

\section{Висновки}

Наявність великої кількості пунктів пропуску через кордон є додатковими (порівняно з іншими територіями країн) осередками забруднення грунтів сільськогосподарського призначення: зростають викиди у атмосферне повітря та кількість твердих відходів, споживається більше води, відповідно збільшується кількість стічних вод і навантаження на очисні споруди. При цьому існує постійна загроза транскордонного забруднення і аварій систем водопостачання, а отже, потрапляння викидів різного ступеню небезпечності.

Показники використовувані для потреб статистики у Польщі (ЄС) і Україні суттєво відрізняються, що великою мірою перешкоджає проведенню повного порівняння стану навколишнього середовища і умов життя населення, які апріорі визначають якість життя, його тривалість, стан здоров'я жителів територій 3 обох боків кордону. У цьому контексті необхідно згадати статтю 356 глави 5 Угоди, котра говорить, що Україна зобов'язується гармонізувати українську статистичну систему з Свропейською статистичною системою, а також підтримувати впровадження загальної системи управління якістю в усі процеси виробництва та поширення статистичної продукції. Окремо, у статті 357 наголошено на співробітництві сторін в рамках Європейської статистичної системи, а саме Євростату як статистичного органу ЄC, у сфері статистики навколишнього середовища.

Перспективи подальших досліджень. Перспективою подальшого дослідження є вивчення структури сільськогосподарського виробництва українськопольського прикордоння 3 акцентуванням уваги на органічному виробництві і споживанні.

\section{References}

Belej, S. I., \& Luzhyns'kyj, V. O. (2020). Sil's'ki terytorii' - centry ekonomichnoi' aktyvnosti jevroregional'nogo spivrobitnyctva v systemi garantuvannja ekonomichnoi' bezpeky. Internauka. Serija: "Ekonomichni nauky", 1. [Elektronnyj resurs]. doi: 10.25313/25202294-2020-1-5559 (in Ukrainian).

Departament ekologii' ta pryrodnyh resursiv L'vivs'koi' oblasnoi' derzhavnoi' administracii' [Elektronnyj resurs]. URL: https://deplv.gov.ua/potochni-rezultaty (in Ukrainian).

Dovkillja L'vivs'koi' oblasti (2018). Statystychnyj zbirnyk. Golovne upravlinnja statystyky u L'vivs'kij oblasti. L'viv: Golovne upravlinnja statystyky u L'vivs'kij oblasti (in Ukrainian).

Kuzubov, A. (2017). The mechanism for ensuring the production of environmentally friendly agricultural products. Russian Journal of Agricultural and SocioEconomic Sciences, 10(70), 191-198. doi: 10.18551/rjoas.2017-10.27 (in Russian).

Nowotny, J., \& Veziroglu, T. N. (2019). Impact of hydrogen on the environment. Alternative Energy and Ecology (ISJAEE), 01-03， 16-24. doi: 10.15518/isjaee.2019.0103.016-024.

Regional'na dopovid' pro stan navkolyshn'ogo pryrodnogo seredovyshha u L'vivs'kij oblasti v 2019 roci (2020). Departament ekologii' ta pryrodnyh resursiv L'vivs'koi' oblasnoi' derzhavnoi' administracii'. L'viv: L'vivs'ka oblasna derzhavna administracija (in Ukrainian).

Salisbury, D. H., Lopez, J. B., \& Alvarado, J. W. V. (2011). Transboundary political ecology in Amazonia: history, culture, and conflicts of the borderland Ashâninka. Journal of Cultural Geography, 28(1), 147-177. doi: 10.1080/08873631.2011.548491.

Suryana, N. K., \& Pudjiwati, E. H. (2017). Social empowerment to achieve food security at the borders: a case study at north sebatik subdistrict of nunukan regency (north Kalimantan province, Indonesia). Russian Journal of Agricultural and Socio-Economic Sciences, 10(70), 13-17. doi: 10.18551/rjoas.2017-10.03.

Ugoda pro asociaciju mizh Ukrai'noju, z odnijei' storony, ta Jevropejs'kym Sojuzom, Jevropejs'kym spivtovarystvom z atomnoi' energii' i i'hnimy derzhavamy-chlenamy, z inshoi' storony: Zakon Ukrai'ny vid 16.09.2014 № 1678-VII. URL: https://zakon.rada.gov.ua/laws/show/984 011 (in Ukrainian).

Urząd Statystyczny w Lublinie [Electronic resourse]. Access mode: https://lublin.stat.gov.pl (in Polish).

Zelich, V. V. (2018). Teoretychni zasady zdijsnennja transkordonnogo spivrobitnyctva pidpryjemstv. Ekonomika i suspil'stvo, 19, 756-762. doi: 10.32782/2524-0072/2018-19-115 (in Ukrainian). 